\title{
Comments
}

\section{PRETRIAL RELEASE UNDER CALIFORNIA PENAL CODE SECTION 853.6: AN EXAMINATION OF CITATION RELEASE†}

California Penal Code section 853.6 establislies police-initiated pretrial release of misdemeanor arrestees by issuance of a citation. Citation release under this statute avoids the two major defects of traditional pretrial release systems: the requirement of bail $^{1}$ and the delay caused by judicial review. Despite these advantages, very few jurisdictions have thus far made use of citation release. Oakland California, however, instituted a comprelrensive citation release program in early 1970 that might serve as a model for other nnunicipalities.

This Comment analyzes both the theory and practice of such a program. Part I compares citation release to several otlier methods of pretrial release. Part II presents a detailed case study of the development, implementation, and operation of citation release in Oakland.

\section{I}

\section{The Theory and Practice of Pretrial Release}

While pretrial incarceration ensures tlrat the arrestee will appear at his trial, it works severe lardships upon both the state and the suspect. Incarceration requires an outlay of public funds, ${ }^{2}$ and simce

$\dagger$ The author wishes to acknowledge his gratitude to the officers and staff of the Oakland Police Department, especially C.R. Gain, Chief of Police, Linda Moody, Legal Advisor, and Kathy Gumpel and Bill Soo Hoo, student interns, without whose lielp this Comment could not have been completed.

1. Although initially the citation recipient need not post bond, the statute allows the judge to impose bail at a later time. CAL. PENAL CODE $\$ 853.6(\mathrm{e})$ (West 1970). The experience of those cities having significant citation programs has been that judges rarely, if ever, impose bail on nondefaulting citation recipients. See notes 32 \& 119 infra and accompanying texts.

2. The dollar amounts of these outlays will vary between communities, but they must include the costs of feeding, caring for, and supervising the prisoner. The most complete figures on the cost of detention come from New York City where, in 1962 , a total of $1,775,778$ jail-days costing over $\$ 10,000,000$ ( $\$ 6.25$ per day) were spent in pretrial detention. D. Freed \& J. WALD, BAIL IN THE UNTTEd StaTes: 1964, at 41 (1964) (a report to the National Conference on Bail and Criminal Justice, Washington, D.C.) [hereinafter cited as FREED \& WALD]. 
the defendant cannot work, his family may become a financial burden upon the state. $^{3}$ Also, incarceration raises serious questions of deprivation of due process, simce studies have shown that defendants jailed before trial generally fare worse in court than those who avoid pretrial detention. ${ }^{4}$ The objective of a pretrial release system should be to insure the arrestee's presence in court for trial, while avoiding these hardships.

Traditional pretrial release procedures allow only judges to release arrestees after bail is posted or, on rare occasions, by release on the defendant's own recognizance (O.R.). ${ }^{5}$ The following section compares these traditional procedures to citation release.

\section{Bail $^{\mathrm{a}}$}

\section{A. Traditional Modes of Pretrial Release}

Historically, an arrestee posted bail out of his own assets ${ }^{7}$ and failure to appear worked a forfeiture of the property. Eventually, the bonding system developed, under which an arrestee paid a fee to a bondsinan who in turn promised to pay bail to the court should the defendant fail to appear. ${ }^{8}$ Although allowing an arrestee to reınain free

3. See generally FREED \& WALD, at 39-48. See also Halverson, Ticketing for Minor Crimes: Will it Work in Evanston? Christian Science Monitor, Sept. 14, 1971, at 2 , col. 2.

4. See D. Kuykendall \& R. Deming, Pre-Trial Release in Oakland, CalIFORNIA 73 (1967) [hereinafter cited as PRE-TRIAL ReLEASE]:

Table 1. Outcome of Principal Charge in Non-Traffic Misdemeanors

\begin{tabular}{lcccccc}
\hline & \multicolumn{6}{c}{ Percent } \\
\cline { 2 - 8 } Outcome & \multicolumn{2}{c}{ Jail } & \multicolumn{2}{c}{ Bail } & \multicolumn{2}{c}{ O.R. } \\
\hline & 1963 & 1965 & 1963 & 1965 & 1963 & 1965 \\
\cline { 2 - 8 } Acquittal & 1 & 3 & 5 & 5 & 13 & 13 \\
Dismissal & 21 & 27 & 29 & 24 & 54 & 25 \\
$\begin{array}{c}\text { Pleaded Guilty to } \\
\text { Original Charge }\end{array}$ & 71 & 60 & 51 & 38 & 33 & 28 \\
$\begin{array}{c}\text { Pleaded Guilty to } \\
\text { Reduced Charge }\end{array}$ & 3 & 3 & 6 & 14 & $*$ & 15 \\
$\begin{array}{c}\text { Conviction by } \\
\text { Court or Jury }\end{array}$ & 4 & 7 & 10 & 18 & $*$ & 19 \\
\hline
\end{tabular}

* no sample cases

See also FREED \& WALD, supra note 2, at 45-48.

5. See generally FREED \& WALD, supra note 2 , at 69.

6. For a comprehensive summary of the history of bail see Note, Bail: $A n$ Ancient Practice Reexamined, 70 YALE L.J. 966 (1961).

7. See Freed \& WaLD, supra note 2, at 1-8.

8. Id. at 22-38. The standard premiun rate in the United States seems to be 10 percent. This rate prevails in Atlanta, Cincinnati, Detroit, Denver, St. Louis, Illinois, California, and most federal courts. Rates as high as 12 percent have been reported in Wisconsin, and 20 percent on some offenses in Birmingham. Within 
on bail while awaiting his trial cannot assure appearance as does pretrial incarceration, the bail system has recorded an extrennely low rate of default (percentage of persons failing to appear in court). ${ }^{9}$ The low default rate cannot, however, be attributed to the financial stake. Under the bonding system the arrestee often has little or no financial stake since the bondsinan's fees are nonrefundable. Therefore, unless the bondsinan has obtained a security interest in property owned by the arrestee, the arrestee incurs no immediate financial loss by failing to appear as scheduled.

Although bail bonding allows a large number of people to make bail, it suffers from serious inherent disadvantages. ${ }^{10}$ First, many people cannot afford to pay the nonrefundable fees demanded by the bondsinan. Also, bondsmen hesitate to post bond for persons lacking sufficient attachable property or a cosigner to cover the amount of bail in case of a default. ${ }^{11}$ Further, bail is often unavailable to the misdeneanor arrestee; soine bondsmen refuse to handle low bails thinking that the fees are inadequate to justify the effort. ${ }^{12}$ Thus, an arrestee whose bail falls below this minimum and who lacks adequate resources of his own has no way to obtain his release. Finally, the bonding procedure places the final decision of whether the arrestee will be released in the bondsman's hands. As Judge Skelley Wright has said:

[T] he professional bondsmen hold the keys to the jail in their pockets. They determime for whom they will act as surety, who in their judgment is a good risk. The bad risks in their judgment, and the ones who are unable to pay the bondsman's fees remain in jail. The court and the commissioner are relegated to the relatively unimportant chore of fixing the amount of bail. ${ }^{13}$

the legal maximums, however, bondsmen frequently bargain for special rates, particularly in high-volume, low-risk offenses like gambling. Disputes between bondsmen about price-cutting are not uncommon, and neither are allegations of illegal overcharging. Id. at 23-24.

9. Wiee \& Simon, Pretrial Release: A Survey of Alternative Practices, 34 FED. Probation 60, 63 (1970) [hereinafter cited as Survey].

10. For an excellent treatment of the problems of a money bail system see Foote, The Coming Constitutional Crisis in Bail, 113 U. PENN. L. Rev. 959 (1965). See also Comment, Tinkering with the California Bail System, 56 CALIF. L. Rev. 1134 (1968).

11. Comment, supra note 10 , at 1140 .

12. For example, during a study of the effect of citation release done by student interns K. Gumpel and W. Soo Hoo, for the Legal Division of the Oakland Police Department during July 1971, it was discovered that bondsinen in the Oakland area would not write bonds for bails of less than $\$ 150$. Information on file with the Legal Advisor's Office, Oakland Police Department.

13. Pannel v. United States, 320 F.2d 698, 699 (D.C. Cir. 1963). See also Iaing, Freedom at a Price, Wall St. J., Oct. 7, 1971, at 1, col. 1. 


\section{Bail Reform: The Illinois 10 Percent Plan ${ }^{14}$}

Dissatisfaction with traditional methods of pretrial release has led several jurisdictions ${ }^{15}$ to experiment with new techniques. Most such programs, however, still operate within the framework of the money bail system. Illinois has one of the more comprehensive of these bail reform programs. Current procedures in that state allow three types of pretrial release: ${ }^{16}$ O.R.; a security deposit of real or cash assets equivalent to the total amount of bail; and release upon posting of 10 percent of the face value of the bail. This fee is posted with the court and therefore all but eliminates the need for the professional bondsman. ${ }^{17}$

The 10 percent feature operates quite simply. The defendant may sign a bond and deposit 10 percent of full bail at any time after bail has been set. The bond conditions release upon a promise to appear in court for trial. Unless the court orders otherwise, when the defendant appears in court as scheduled and the case has been finally resolved, he receives 90 percent of his original 10 percent deposit back. ${ }^{18}$ Thus, the defendant who appears as scheduled forfeits only 1 percent of the face value of his bail.19 The Illinois plan appears to provide at least as effective a guarantee of court appearance as does traditional bail bonding. ${ }^{20}$

Yet, while the Illinois plan alleviates many of the problems inherent in bail bonding, it does not remove all of them. First, the defendant must still obtain 10 percent of the bail to deposit with the court in order to obtain his release. Second, the major fault of all money bail systems, rehance on the posting of money to insure the defendant's return, ${ }^{21}$ remaims; the whole system turns on ability to pay. ${ }^{22}$

14. For a detailed explanation of the Illinois plan, see Bowman, Illinois Ten Per Cent Bail Deposit Provision, 1965 ILL. L.F. 35; Kamin, Bail Administration in lllinois, 53 IrL. B.J. 674 (1965).

15. Among these jurisdictions are the federal government, New York, and Illinois.

16. Ill. CODE CRIM. PRo. ch. 38, § 110-2, 7 (Smith-Hurd 1970).

17. Survey, supra note 9 , at 63 .

18. IrL. CODE CRIM. PRo. ch. 38, \& 110-6(f) (Smith-Hurd 1970).

19. In the event of default, the court orders the forfeiture of the full amount of bail. If the defendant has not appeared after 30 days, the court enters an enforceable judgment for the full amount of bail plus costs in favor of the state. ILL. CODE CRmM. Pro. ch. 38, \& 110-6(g) (Smith-Hurd 1970). Additionally, as in most jurisdictions, failure to appear constitutes a separate punishable offense under llinois law. IIL. CODE CRIM. Pro. ch. 38, $\$ 110-2,7$ (g), 32-10 (Smith-Hurd 1970).

20. Wice and Simon report default rates of 17 percent for traditional bail practice, 16 percent for O.R., and 18 percent for the Illinois plan. Survey, supra note 9, at 63.

21. See Presidents's Commission on Law Enforcement and the AdministraTION OF JUSTICE, TASK FORCE REPORT: THE COURTS 37 (1967) [hereinafter cited as TASK FORCE REPORT].

22. See 2.1 Weeriy Compilation of Presidential Documents 819 (June 27, 


\section{Release on One's Own Recognizance ${ }^{23}$}

O.R. allows arrestees to be released without posting bail. Despite this lack of financial incentive, statistics from various O.R. projects reveal no substantial difference between the default rate claimed by the bail bondsinan and that recorded for O.R. ${ }^{24}$

Although O.R. goes a long way towards reheving the inequities of money bail, it too suffers from serious handicaps. The decision to O.R. a defendant can be made only by a judge, and judges are hesitant to O.R. a defendant about whom they have bittle information. ${ }^{25}$ Consequently, O.R. projects have been established in several cities to provide judges with necessary information. These projects gather background inforination on arrestees and report their findings to the judge, who uses thein in determining whether to O.R. the defendant. Although O.R. projects have helped to increase the number of O.R.'s granted, ${ }^{26}$ the O.R. process is both time consuming ${ }^{27}$ and expensive. ${ }^{28}$ These factors create yet another problem with O.R.: Due to limited resources, O.R. project directors must establish priorities; often the misdemeanor arrestee, whose bail will be only a few hundred dollars, will

1966) (remarks of former President Johnson at the signing of the Federal Bail Reform Act of 1966 [18 U.S.C. $\$ 3146$ (1970)]).

23. For an excellent treatment of release on one's own recognizance, see BRITTSH

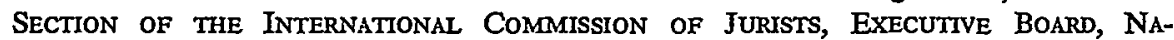
tional Conference on BaIl and CRTMINal Justice, BaIl aNd Summons: 1965 (1965) (proceedings of the Institute on the Operation of Pre-Trial Release Projects, New York City, October 1965 and proceedings of the Justice Conference on Bail and Remand im Custody, London, England, November 1965). See also A. SchafFer, The Problem of Overcrowding IN THE DETENTION Institutions OF New York CitY: AN ANALysis of Causes and ReCOMmendattons for ALlevtation (1969) (a report to the Mayor's Criminal Justice Coordinating Council by the Vera Institute of Justice.)

24. Survey, supra note 9 , at 63.

25. As a result, O.R. has been only minimally used. See Pre-Trual Release, supra note 4 , at 69 .

26. Id.

27. Information on the arrestee must be gathered, verified, and presented to a judge, who must then review it and make a determination. This process may take anywhere from 1 hour to 1 week or longer. Comment, supra note 10, at 1153-54.

28. Although the mcarceration costs saved can partially balance the dollar outlay necessary to support an O.R. project, such a project requires substantial resources to operate on a large scale. Aside from clerical costs, the project must have a staff of people to interview arrestees, verify the information, and do followup work designed to insure that the defendant appears in court as scheduled. The costs of such a system are so great that Ken Babb, director of the San Francisco O.R. Project, indicated that his program could not survive without the aid of Vista workers and other voluntcers. Even with this assistance the San Francisco O.R. Project has financial difficulties that may prove debilitating. Interview with Ken Babb, Director of the San Francisco O.R. Project, in San Francisco, November 1970 [heremafter cited as Babb Interview]. 
be ignored in favor of the felony arrestee whose bail will be many times higher. ${ }^{29}$

These circumstances indicate the need for a procedure providing bail-free release for misdemeanor arrestees. By using such a program in conjunction with O.R., the problems of pretrial detention could be alleviated for both felony and misdemeanor arrestees.

\section{B. Citation Release}

Section 853.6 of the California Penal Code ${ }^{30}$ authorizes police release of misdemeanor arrestees without removimg the arrestee from the judicial process ${ }^{31}$ and without requiring him to post bail. ${ }^{32}$ This procedure, known as citation release, ${ }^{33}$ takes two forms: field release by the arresting officer prior to booking the defendant ${ }^{34}$ and jail or station house release after the defendant has been booked. ${ }^{36}$ Should the arresting officer fail to release the arrestee, the department must conduct a background imvestigation of the defendant immediately upon completion of booking and consider him for station house release. ${ }^{36}$ The code provides that the citation, when filed with the court, becomes a complaint to which the defendant may plead guilty

29. Babb Interview, supra note 28. Mr. Babb indicated that except on those rare occasions when there were either no felony cases or a very special set of circumstances, misdemeanor arrestees were ignored by the project. He described this as a necessary policy decision that had to be made so that the project's resources would be allocated where they would do the most good. Id.

30. Cal. Penal Code $\$ 853.6$ (West 1970).

31. Section 849(b)(1) [CAL. Penal CODE (West 1970)] authorizes a peace officer to release any person from custody when "he is satisfied that thcre are insufficient grounds for making a criminal complaint against the person arrested." Subsection (c) [id. $\$ 849$ (c)] provides that the record of a person so released will show the encounter as a detention, not as an arrest.

32. Initial release may be made without bail. The statute allows, but does not require, a judge to set bail for citation recipients when they appear in court. CaL. PenAl CODE $\$ 853.6$ (e) (West 1970). Ideally judges will find no need to use this discretionary power. The fact of an individual's appearance offers strong testimony to his qualifications for O.R. release. For this reason, most citation recipients will avoid having to post bail. See text accompanying note 119, infra.

33. Although operations under section 853.6 have frequently been referred to as "citation in lieu of arrest," [see, e.g., CENTER ON ADMINISTRATION OF Criminal Justice, University of California, Davis, CtTation in Lieu of ARrest For MisDEMEANOR DEFENDANTS IMPLEMENTING THE NEW CALIFORNIA LAW (hereinafter cited as Citation StUdY)] such terminology is misleading. An arrest must occur before the citation can be issued. Cax. Penal CODE $\$ 853.6$ (a) (West 1970). The release procedure is analogous to the issuance of a traffic citation. A valid arrest initiates the judicial process. The absence of or release from physical custody does not alter the legal consequences of the arrest. Properly construed, the citation stands in lieu of bail, not of arrest.

34. Cal. Penal Code $\$ 853.6$ (a) (West 1970).

35. Id. $\S 853.6(\mathrm{i})$.

36. Id. This provision was added to the statute in 1969. 
or nolo contendere. If any other plea is entered, a separate verified complaint must be filed. ${ }^{37}$

\section{Citation-Release Procedures}

Under citation-release, the arresting officer determines whether to cite and release in the field on the basis of his immediate assessment of the arrestee's eligibility and the circumstances of the offense. Since the statute allows only misdemeanor arrestees to be cited, felony suspects are precluded from consideration. If the officer determines that a citation is in order the arrestee is immediately released. If the officer decides not to cite, the arrestee is taken imto physical custody and removed to the local detention facility. Upon arrival at the jail the arrestee undergoes initial booking. After booking, the statute requires that a background investigation be made, ${ }^{38}$ after which the department must determine whether to issue a citation. Any imdividual failing to qualify for citation release may obtain his freedom through the traditional means of pretrial release. ${ }^{39}$

\section{Analysis of Citation Programs Under Penal Code Section 853.6 as a Means of Effectuating Pretrial Release}

The citation systein offers a means to achieve expeditious release without requiring any forfeiture and with no significant increase in the rate of default. ${ }^{40}$ Citation release functions much like O.R. The critical difference between the two forms of release is that only a judge may O.R. an arrestee, while a police officer may cite and release him.

Although citation release avoids many of the mequities of money bail, and the delays of O.R., the California system has certain intrinsic difficulties. First, the absence of statutory standards is of

37. Id. $\$ 853.9(\mathrm{a})$.

38. Id. \& 853.6(i).

39. Although the citation release offers a less expensive means to avoid incarceration, a small number of arrestees elect bail, probably to avoid the background investigation. Records available at the Oakland Police Department (through the office of the Deputy Chief in charge of the jail) indicate that few potentially eligible misdemeanants opt out of the citation process. November 1970 is typical. Of the 522 eligible misdemeanor arrestees received by the jail, 17 refused to give information and 86 posted bail prior to their citation interview. See note 109 infra.

Another reason for the use of bail by a minority of the arrestees lies in the amount of time necessary to obtain release. While a station louse release is designed to operate expeditiously, large groups of contemporaneous in-custody arrests create bottlenecks. Under such circumstances some individuals can get out sooner by posting bail. Interviews with Oakland Police Department jail personnel, August 16-17, 1971 [heremafter cited as Jail Interviews].

40. See text accompanying note 50 infra. 
critical importance. An investigation of all in-custody arrestees, including, but not limited to, the person's name, address, length of residence, marital status, einployment status, and prior record, is mandated by the statute. ${ }^{41}$ No guidelines as to the weight to be accorded these factors appear in the law, however. Consequently, each jurisdiction that establishes a citation system has the freedom to determine the standards for release. While regional variation in citation release standards may be necessary, due process and equal protection require minimum standards below which no community should be allowed to operate..$^{42}$

Second, the statute leaves the decision whether to cite an arrestee in the field to the arresting officer's discretion. Here, as in any situation where discretionary power may be exercised, there is a potential for abuse. ${ }^{43}$ The threat of discretionary abuse should not be disregarded, but neither should it be seen as fatal. Since without a citation systen the arrestee would be forced to depend on the bail or O.R. systems, the decision not to cite leaves the arrestee in no worse position than he would have been in if citation release did not exist. ${ }^{44}$ To prevent abuse, however, operational regulations for citation release should be established to confine officer's discretion. While discretionary abuses may occasionally result on a case-by-case basis, experience has shown that well-developed guidelines will prevent any overall pattern of discrimination. ${ }^{45}$

Third, California's citation release statute suffers from too narrow a scope. The statute calls for the use of citation procedures solely for misdemeanor arrestees. While it may be reasonable to exclude arrestees suspected of serious felonies (those involving either as-

41. Cal. Penal Code § 853.6(i) (West 1970).

42. Without minimum standards there are no safeguards against the abuse of discretion, nor any controls over substantially differing legitimatc exercises of discretion. Absent such standards, persons in virtually identical situations may receive radically different treatment: one being cited and released, the other being incarcerated.

43. While the statute does not create a separate cause of action for a person not cited due to an abuse of discretion, a wrongfully detained arrestee would not be barred from judicial recourse. Because an arbitrary decision to deny a citation would result in incarceration, an action should he in either California or federal court for a violation of the arrestee's civil rights. See CAL. Gov'T CODE \& 844.6(c) (West 1970) and 42 U.S.C. $\$ 1983$ (1971).

44. These arguments also serve to rebut any criticism of citation release as fostering excessive pretrial detention. Since the bail system suffices to prevent unconstitutional pretrial detention, and the worst that can happen to an arrestee denied citation release is that he will be relegated to the bail system, then arguably, a denial of citation release would not result in unconstitutional pretrial detention. See american Bar Association Project on Minimum Standards for Criminal Justice, Standards Relating to Pretrual Release (approved draft, 1968) at 10, § 2.1.

45. See Tables A, B \& C, Appendix I and text following note 119 infra. 
sault or the use of dangerous weapons), there is no good reason to exclude all felony arrestees from consideration. Certain crimes appear more serious than others only because the legislature has labeled them felonies and not because their perpetrators are more likely to repeat the offense or less likely to appear in court. Furthermore, many of these felony arrestees end up charged with only misdenieanors. ${ }^{46}$ The distinction between felonies and misdemeanors is especially tenuous with regard to those persons charged with crimes that by law can be either felonies or misdemeanors. ${ }^{47}$ Although a large portion of such crimes eventually end up as misdemeanors, police departments frequently process all such crimes as felonies. ${ }^{48}$ In such cases there is little justification for prohibiting citation release, ${ }^{49}$ though perhaps nonassaultive felony arrestees should be excluded from consideration for field citation in order to ensure proper booking and identification of the suspect, but should be considered for jail citation once booking is completed.

In spite of these difficulties, the citation release procedures set up by the statute are basically sound. Statistics reveal that the rates

46. TASK Force Report, supra note 21 , at 10-11. See also S. KaDish \& M. Paulsen, Crnminal Law and Its Processes 1125-30 (1969). This often results from plea bargaining and consequent charge reduction.

47. See Cal. Penal Code $\$ 17$ (West 1970).

48. As a practical result of CaL. PeNal Code $\$ 17(\mathrm{~b})$ (West 1970), allowing judicial determination of the degree of an offense (as a felony or a misdemeanor), law enforcement agencies feel bound to assume the felony for purposes of processing the arrest. This is standard operating procedure in Oakland, and presumably throughout the state. See Oakland Calif., Police Department General Order M-70, Citations for Adult Misdemeanors, Feb. 18, 1970, III-A at 2 [heremafter cited as General Order].

49. The distinction between felonies and misdemeanors may be wholly irrelevant for purposes of pretrial release. More proper concerns would be the likelihood of a continuation of the offense and the probability that the arrestee will appear in court. Indeed, some have argued that bail-free release progranis should be extended to all felony arrestees. They contend that the arguments against the money bail and O.R. systems apply at least as strongly to felony as to misdenieanor arrestees. In fact, O.R. projects dealing with felons have been able to report comparably low default rates between the two classes of arrestees:

Table 2. Extent of Failure to Appear for Court Hearings Among Project Investigated Cases Granted O.R.

\begin{tabular}{cccc}
\hline Type of Crime & $\begin{array}{c}\text { O.R.'s } \\
\text { Granted }\end{array}$ & Defaults & $\begin{array}{c}\text { Percent } \\
\text { Defaulting }\end{array}$ \\
\hline Eligible Misdemeanors & & & \\
Positive recommendations & 579 & 34 & 5.9 \\
Negative recommendations & 84 & 14 & 16.7 \\
Eligible Felonies & 46 & 2 & 4.4 \\
$\quad$ Positive recommendations & 4 & 0 & 0.0 \\
Negative recommendations & 9 & 2 & 22.2 \\
Courtesy Investigations & 62 & .0 & 0.0 \\
Positive recommendations & Negative recommendations & &
\end{tabular}

Pre-Trial ReIEASE, supra note 4, at 86. 
of appearance for arrestees released by citation are substantially the same as for those who posted bail. ${ }^{50}$ If the justification for bail lies in the assurance that the arrestee will appear in court, citation release achieves that goal while mitigating many of the mequities of a money bail system. First, by allowing release without deposit, citation release avoids differential treatment of the indigent. Next, citation release, unlike O.R., avoids delay by allowing field and jail release by police early in the pretrial process. Most important, citation release avoids depriving arrestees of liberty or property before they have had a trial to determine guilt or innocence.

50.

Table 3. Rate of Appearance, Contra Costa County, One Month 1969, All Forms of Release

\begin{tabular}{lcccc}
\hline Jurisdiction & $\begin{array}{c}\text { Total } \\
\text { Number } \\
\text { Charged }\end{array}$ & $\begin{array}{c}\text { Total } \\
\text { Number } \\
\text { Released }\end{array}$ & $\begin{array}{c}\text { Number } \\
\text { Failing } \\
\text { to Appear }\end{array}$ & $\begin{array}{c}\text { Percentage } \\
\text { Appearing }\end{array}$ \\
\hline Concord & 38 & 31 & 2 & 94 \\
Contra Costa & 77 & 65 & 4 & 94 \\
Sheriff & 43 & 24 & 1 & 96 \\
Pittsburgh & 133 & 111 & 9 & 92 \\
Richmond & 53 & 40 & 0 & 100 \\
San Pablo & 21 & 15 & 0 & 100 \\
\hline Walnut Creek & 365 & 286 & 16 & 94 \\
\hline \multicolumn{1}{c}{ Total } & & & & \\
\hline
\end{tabular}

Citation Study, supra note 33, at 11.

For citation release only, the following figures were reported:

Table 4. Rate of Appearance, Contra Costa County, One Month 1969, Jail Citation Releases

\begin{tabular}{lccc}
\hline Jurisdiction & $\begin{array}{c}\text { Number of } \\
\text { Jail Releases }\end{array}$ & $\begin{array}{c}\text { Number Failing } \\
\text { to Appear }\end{array}$ & $\begin{array}{c}\text { Percentage } \\
\text { Appearing }\end{array}$ \\
\hline Concord & 1 & 0 & 100 \\
Contra Costa & 15 & 2 & 87 \\
Sheriff & 15 & 1 & 93 \\
Pittsburg & 76 & 9 & 88 \\
Richmond & 17 & 0 & 100 \\
San Pablo & 12 & 0 & 100 \\
Walnut Creek & 136 & 12 & 91 \\
\hline \multicolumn{1}{c}{ Total } & & &
\end{tabular}

Id. at 5 .

Only a few Contra Costa County jurisdictious employ field release procedures. The results reported for field release, however, compare favorably to those for jail release.

Table 5. Rate of Appearance, Contra Costa County, One Month 1969, Field Citation Release

\begin{tabular}{cccc}
\hline Jurisdiction & $\begin{array}{c}\text { Number of } \\
\text { Field Releases }\end{array}$ & $\begin{array}{c}\text { Number Failing } \\
\text { to Appear }\end{array}$ & $\begin{array}{c}\text { Percentage } \\
\text { Appearing }\end{array}$ \\
\hline Concord & 9 & 0 & 100 \\
Contra Costa & 24 & 2 & 92 \\
\hline Sheriff & 33 & 2 & 93 \\
\hline Total & & &
\end{tabular}

Id. at 6 . 
The use of citation release affords advantages to the community as well. Regardless of whether the local law enforcement agency requires the arresting officer to personally accompany the arrestee to jail, or has a special unit to transport the arrestee, the transportation process consumes time and money; this money is saved by field release. Stationhouse release, while less economical than field release, allows considerablc savings in costs for jailing, transporting to court, and so forth. ${ }^{51}$ The savings in time and money afforded by citation release allow increased police services at no additional cost to the taxpayer. $^{52}$

\section{III}

\section{Citation Release in Oakiand: A Case Study}

The city of Oakland has one of California's most comprehensive citation programs. The Oakland program ${ }^{53}$ includes both field and jail citations ${ }^{54}$ for misdemeanor arrestees. ${ }^{55}$ Measured by default rate, level of utilization, and savings of time and money, the Oakland program has been a success. Oakland's success should encourage other cities to institute similar systems for pretrial release of misdeineanor arrestees.

51. While general estimates are not available, the Center on Administration of Criminal Justice, University of California at Davis suggests that the savings in time realized by a typical department through the use of citation release might work out on a per case basis as follows:

Field Citation:

30-40 minutes transportation and booking time

1-2 days of jail detention

15-30 minutes of officer time for transportation to court.

Jail Citation:

1-2 days of jail detention

15-30 minutes of officer time for transportation to court

30 minutes time to complete the complaint.

In the case of a field citation, the citation form itself serves adequately as a complaint form in accordance with CaL. Penal Code $\$ 853.9$ (a) (West 1970). Citation Study, supra note 33 , at 8.

See also L. Moody, Expenses Saved by Misdemeanor CtTation Program (chart prepared for Oakland Police Department) (1971).

52. Further savings can be realized by coupling the citation release with a citation hearing process. The liearing provides an infornal means of resolving the problem out of court. In sucli a system, the district attorney, after reviewing the file, determines whether or not a citation hearnig would be likely to result in resolution of the problen. If he determines that it would, lie schedules a liearing. Citation hearings have been successfully employed by the city of Oakland. See Hederman \& Dahlinger, Citation Hearing System, 12 HAST. L.J. 275 (1961).

53. The Oakland prograin started on February $25,1970$.

54. General Order, supra note 48, at 1.

55. Id. 


\section{A. Substantive Problems of Establishing Citation Release in Oakland}

Due to the absence of statutory guidelines, Oakland was forced to decide numerous substantive issues prior to instituting citation release. The most significant of these issues involved questions about the scope of the program and the degree of officer discretion.

\section{Scope of the program $^{50}$}

Although the Penal Code provides for citation release consideration for all misdemeanor arrestees, ${ }^{57}$ Oakland felt at first that there might be policy justifications for imposing more narrow limits on its program. Yet after careful study, Oakland chose to impose only slight limitations. As the program proved successful and statutory ambiguity was resolved, even these limitations were ultimately lifted. ${ }^{58}$

The first limitation considered was whether specific misdemeanors should be excluded from citation release. Proponents of this limitation contended that certain offenses are so dangerous, or so likely to continue, that offenders should be automatically excluded from consideration for release. Sucl exclusion entails more difficulties than it avoids, however. A list of excluded offenses is, by its very nature, arbitrary. Certainly, within the class of all persons accused of any given offense there may be some who deserve citation release. A mucl sounder approach rests the ultimate determination on general guidelines for eligibility set out in departmental regulations such as Oakland's General Order. ${ }^{59}$ The grant or demial of citation release should relate to the individual, not to the offense; a well-formulated set of standards should base ehgibility for release on the particular facts of the arrest.

Resisting arrest posed a similar problem. Due to the nature of this offense it can easily be construed as indicating an unwillingness to

56. Elements of this issue are also considered elsewhere in this Comment. See notes 46-50 supra and accompanymg text.

57. CaL. Penal Code $\$ 853.6$ (a) (West 1970).

58. The department was unsure at first of the status of Vehicle Code arrestees under section 853.6. An opinion from the Oakland City Attorney assured Police Chief Gain that sucl arrestees were eligible. Subsequently, these arrestecs were treated the same as other arrestees. Memorandum of October 20, 1970 from Oakland Police Chief C.R. Gain to pohice personnel.

59. See text accompanying notes 82-89 infra. L. Moody, Final Report SUd-

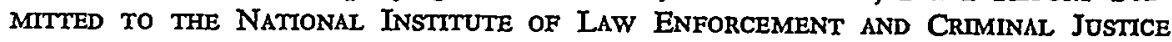
From the LAWYeR's COMMITTEe FOR Civil Rights UNDER LAW (ProJect TITLE: An Expermant In Using Legal SkILIs to Reduce Police-Community Hostility) 6 (1969), on file with the Oakland Pohice Department, Office of the Legal Advisor. [heremafter cited as FINAL REPORT]. 
cooperate with the judicial system, and hence that the person arrested is a potential bad risk. Although Oakland decided that the General Order's discretionary guidelines should control, ${ }^{80}$ it is doubtful that resistance will invoke the favorable exercise of discretion by the officer. The extent of the resistance will be important, but it seems reasonable to expect that in practice resisters will at least be denied field release.

Family disputes also presented a difficult problem. ${ }^{61}$ Citation issuance and immediate release of the arrestee may open the door to more serious infractions if the dispute continues. On the other hand, only some domestic disputes will result im continued problems if the offender is released; following general guidelines seemed to be the best course of action. ${ }^{62}$ Oakland has also established a very successful Family Crisis Intervention Unit (FCIU) whose specially trained officers are the first called to handle a family dispute. These officers seek to mitigate the problem and to prevent its recurrence by referring family members to an appropriate agency, welfare or counseling for instance. If these efforts fail, or if the officers of the FCIU are employed elsewhere, the normal citation procedures apply. ${ }^{63}$

The manner of dealing with a citizen's arrest also received special consideration by the department, ${ }^{64}$ and the department decided that a citizen's arrestee should be eligible for field and jail citation. Neither the quality of the offense, nor the arrestee's qualifications for citation differ when a private citizen, rather than a police officer, effects the arrest. Naturally, an arresting citizen's demand that the arrestee be incarcerated is often vindictive; it should be disregarded in determining whether to issue a citation. The officer should consider, however, any otherwise valid reason (e.g. propensity towards continuation of the offense) on which the citizen's demand may be based.

Certain misdemeanor offenses, such as shoplifting, may constitute a felony if the arrestee has prior convictions. Therefore, in citing a shoplifter the officer might be issuing a citation to a felony arrestee. Since it was presuned that a large percentage of citations would be issued for shoplifting, ${ }^{65}$ however, Oakland decided not to prohibit citation in all such arrests. ${ }^{68}$ Rather, the arresting officer requests a

60. Id.

61. See notes $102 \& 103$ infra and accompanying text.

62. Final REPORT, supra note 59, at 7.

63. Interviews im Oakland with Ms. Linda Moody, Legal Advisor, Oakland Police Department, March 27, 1972 and Officer Whalley of the Family Crisis Intervention Unit, Oakland Police Department, April 3, 1972.

64. FINAL RePorT, supra note 59, at 7.

65. Id. This assumption was borne out in fact as indicated by the data in Tables D-F, Appendix II.

66. FINAL REPORT, supra note 59, at 7. 
check on the arrestee's record. If the arrestee has a local record of shoplifting it will appear in the Oakland files and no citation will be issued. If no local record appears the normal citation release criteria apply. Should it later be discovered that the arrestee had a shoplifting record that did not appear in the Oakland files a warrant for arrest can always be issued.

Finally, the juvenile arrestee presented a problem deserving special attention. Prior to implementation of misdemeanor citation release, Oakland had been following a comprehensive citation program for juveniles. Simce the two programs employ different forms and routing procedures, and smce different courts and pretrial procedures are involved, it did not seem feasible to combine the two programs. ${ }^{07}$ Other jurisdictions seeking to employ citation release, that do not currently have juvenile citation procedures, should consider either establishing separate procedures for juveniles or modifying their citation program to allow for the citation of juveniles.

\section{Degree of Officer Discretion ${ }^{68}$}

One important issue was whether citation issuance should be completely discretionary. Oakland decided that it should not; ${ }^{00}$ the presumption is that the officer will issue a citation. He has, however, limited discretion to determine an individual's eligibility in accordance with the standards established in the General Order. Furthermore, Oakland requires that the officer report his reasons for any refusal to cite. This orientation provides a strong impetus for use of the citation procedures. By taking such a stance, the police administration made all officers aware of the program's purposes and priorities. Had this position not been taken, it appears doubtful that Oakland's experience would have been so successful.

The imclusion of both jail and field release procedures resulted in two problems; first, whether the criteria for release should be identical; and second, whether jail officers should be required to contact the arresting officer prior to issuing a jail citation. Oakland answered both questions in the negative. ${ }^{70}$ The statute distinguishes between field and jail citations; ${ }^{71}$ consideration for jail citation is mandatory. Therefore, Oakland took the position that unless the circumstances indicated a high risk of default, or a necessity of incarceration for the

67. $I d$., at 6 .

68. See note 60 supra and accompanying text.

69. FINAL REPORT, supra note 59, at 6 .

70. Id., at 6-7.

71. See text accompanying note 34 supra. 
public safety, jail release was mandatory. ${ }^{72}$ In keepmg with this position, the procedure demands a de novo review by the jail officers. ${ }^{73}$ Requiring the arresting officer's approval for a jail citation would violate these principles by rendering the jail officer's discretion subordinate to the field officer's. ${ }^{74}$ Furthermore, because more information is available to the jail officers, their investigation is more detailed and they can einploy criteria in addition to those utilized by field personnel. Hence, communication between jail and field personnel should not be a prerequisite to a decision to release.

\section{B. Procedural Problems of Establishing Citation Release in Oakland}

In addition to the critically important substantive questions, several procedural issues had to be resolved. In order that the program could function within the police bureaucracy ${ }^{75}$ it became necessary to resolve such questions as: Which divisions of the department and which outside agencies should receive copies of offense and arrest reports for citation recipients? How should the citation forms be routed? How could notice of the issuance of a jail citation be given to those units that had already received a report of physical arrest? Each of these questions, of course, raised many subissues. ${ }^{76}$ Since citation release requires the cooperation of the police, the District Attorney, and the mumicipal court judges, all three branches of Oakland's criminal justice system were imvolved in the planning of the program and in the preparation of regulations contained in the General Order.

Conferences with the court raised and resolved several difficulties. At the time of receipt of a citation, the recipient must be told where and when to appear im court. The problem of coordimating these dates with the court calendar immediately appeared. This problem was solved by a change in the routing procedure to allow the court clerks to arrange the calendars in accordance with citation appearance dates. ${ }^{77}$ The judges also suggested that there might be problems with warrant arrests. There was strong judicial sentiment against allowing police to second-guess the court by releasing an individual arrested pursuant to a warrant. The final resolution of the warrant issue allowed police to cite and release any person who turned himself

72. Final RePort, supta note 59, at 6.

73. Id.

74. Id.

75. The Oakland Police Department consists of over 700 sworn officers and 250 civilian support personnel. This force is divided into several divisions, subdivisions, and units whose activities must be closely coordinated.

76. Final RePORT, supra note 59, at 9.

77. Id. 
in on a warrant, but exempted from eligibility any person physically arrested by the police pursuant to a warrant. ${ }^{78}$

Discussions with the District Attorney centered around the question of filing the citation with the court. Allowing the police officer to file directly with the court as provided by the statute ${ }^{70}$ appears pro tanto to confer prosecutorial discretion upon the police. Although the California Penal Code ${ }^{80}$ provides that a citation so filed stands in lieu of a complaint only if the defendant enters a plea of guilty or nolo contendere, it was decided that all citations should be routed through the District Attorney's office for initial review. The District Attorney makes the final decision whether to file the citation with the court. ${ }^{81}$

\section{Operation of Citation Release in Oakland}

The operation of Oakland's citation release prograin may be briefly described. After arresting an adult charged with a misdemeanor, the arresting officer "shall" 82 issue a field citation unless the arrestee falls into one of the six in-custody arrest criteria defimed by departinental regulation. ${ }^{83}$ The General Order provides that a citation shall not be issued to:

(1) persons requiring medical examination or medical care, or unable to care for themselves; ${ }^{84}$

(2) persons who will probably continue or resume the offense, or whose continued freedom poses a threat to person or property; $; 8$ ion; ${ }^{86}$

(3) persons unable or unwilling to produce adequate identifica-

(4) persons who seem reasonably unlikely to appear in court; ${ }^{87}$

(5) persons whose continued freedom would jeopardize the prosecution of this or any other offense; ${ }^{88}$

78. General Order, supra note $48, \S$ IV-A-5-b(2) at 7.

79. Cal. Penal Code $\$ \S 853.6(\mathrm{e}), 853.9(\mathrm{a})$ (West 1970).

80. Id. $\$ 853.9$.

81. Final Report, supra note 59, at 8. Penal Code section 853.9 provides for the filing of the citation with the court. Although, according to the statute, the citation when filed shall constitute a coinplaint to which the defendant may plead guilty or nolo contendere, it does not require that the arresting or releasing officer personally file the coinplaint. Nothing in the statute would appear to preclude the screening of citations by the District Attorney's office. CAL. PENAL CODE $\$ 853.9$ (West 1970).

82. General Order, supra note 48 , at 3.

83. Id.

84. Id.

85. Id.

86. Id. at 5 .

87. Id. at 6 .

88. Id. at 5 . 
(6) persons who demand to be taken before a magistrate immediately, or who refuse to sign the citation..$^{89}$

If the officer decides to cite, the arrestee receives instructions on where and when he must appear in court. The officer also instructs him to appear for booking in the Identification Division of the Police Department prior to appearing in court. ${ }^{90}$ The arrestee is then immediately released.

Should the officer decide against citation release, the arrestee is taken to the municipal jail either by the arresting officer, or, more frequently, by a special transportation unit. Once at the jail the arrestee must be booked. His identity and prior record are checked and confirmed. As soon as possible after the completion of this process the sergeant on duty interviews the arrestee to determine whether a jail citation should be issued. These brief interviews allow the sergeant to obtain essential background information about the arrestee, as required by the statute. Under the Oakland procedures the jail sergeant has the initial authority ${ }^{91}$ to decide whether the im-custody arrestee will be cited. Background investigation point forms based on those developed by the Vera Institute for its O.R. project in New York $^{92}$ were developed to assist the sergeant in making his decision. The General Order does not require the release of any arrestee on the basis of a high point total, however, nor does it demand continued incarceration of a low scoring arrestee.

Since a large proportion of the physical arrests for misdemeanor offenses are due to insufficient evidence of identity to qualify for a field citation, ${ }^{93}$ the results of the identification check become crucial. This information and the prisoner's attitude in the citation interview (Is he hostile, or lying, or does he express unwillingness to appear in court?) weigh heavily in the determination of whether a citation will be issued. In practice, the overriding concern expressed by jail persormel was whether the arrestee seemed likely to appear in court. ${ }^{94}$

If a decision is made to cite the arrestee, the sergeant explains the citation process to the prisoner, telling him when and where lie must appear in court. Upon signing the citation and promising to

89. Id. at 7 .

90. Id. at 8-9. See also CaI. Penal CoDe $\S 853.6(\mathrm{~g})$ (West 1970).

91. When the sergeant decides not to cite, his decision is subject to review by superior officers.

92. The Vera Institute devised a form which gives points to an individual in accordance with his personal characteristics (e.g., prior record, employment, residential aud family stability). The Oakland Background Investigation form, while not identical to that of the Vera Institute, follows the same pattern.

93. Jail Interviews, supra note 39.

94. Id. 
appear, the arrestee is released. Once a citation has been issued, the department forwards a copy to the District Attorney. ${ }^{05}$ After reviewing the case the D.A. determines whether to drop the charges, arrange a citation hearing, or go directly to court. If he decides to go directly to court, or if the citation hearing is unsuccessful, the D.A. files a complaint with the court. Froin this point on the procedures are the same as though no citation had been issued.

Although the departmental regulations provide basic guidelines in the form of the in-custody arrest criteria for the field officer and the Vera-like point sheet for jail personnel, the interpretation and application of these guidelines is discretionary. In spite of the potential for great divergence in citation decisions, ${ }^{96}$ certain identifiable tendencies have developed among both field and jail personnel. Although these tendencies may be used for descriptive purposes, it must be remeinbered that in most cases the decision to cite arises from a combination of several interrelated factors, not from any one or two.

\section{Whether the Arrestee has Local Roots ${ }^{27}$}

The factors examined by the officers are family ties, employinent, and length of residence. As a general rule, 1 year of local residence is treated as a minimum requirement. Officers make exceptions to that rule in cases where an imdividual offers other indications of being a good risk. Such other indications might mclude extensivc fanily ties or a steady job. ${ }^{08}$

\section{Whether the Arrestee Can Take Care of Himself}

No one unable to care for himself receives field or jail citations. Once the otherwise eligible arrestee becomes capable of carmg for

95. FINAL REPORT, supra note 59, at 8 .

96. Jail Interviews, supra note 39. Jail personnel indicated varying degrees of willingness to cite individuals under a given set of circumstances. Factors such as prior record, employment status, and length of residence received different weight from different officers.

97. All examples cited in notes accompanying the textual discussion following this note come from the records of the Oakland Police Department. In order to maintain the confidentiality of these records the names of arrestees have been deleted and initials changed. The facts surrounding each case remain unaltered. Copies of the original police reports with the names and other identifying marks blocked out are on file with the California Law Review.

98. For example, F.G., a 37-year-old male, was arrested for petty theft. The arresting officer refused to field cite F.G. as he had been unemployed for a prolonged period, had no family ties in the area, and had resided in Oakland only 6 months. The jail investigation of F.G. revealed a record of 48 misdemeanors and three felonies. Due to F.G.'s transient status and prior record, no jail citation was issued. Conversely, J.F., a 20-year-old male, also arrested for petty theft, was dcnied a field citation because he had no means of identification. Even though he had no job and a minor record, he received a jail citation on the basis of 15 years residence and family ties in the area. 
himself he may be released. The drunk offers a good example of this consideration. After sobering up, if otherwise eligible, he may be cited. ${ }^{99}$

\section{Whether the Arrestee Can Provide Sufficient Identification}

The adequacy of identification is primarily a concern of the arresting officer in his decision whether to field cite. Failure to provide adequate identification probably accounts for more in-custody misdemeanor arrests than any other single factor. ${ }^{100}$ What constitutes sufficient identification varies not only from officer to officer, but also from case to case. Most officers seek something with the arrestee's picture on it, such as a driver's license or an identification card issued to non-drivers by the Department of Motor Vehicles. Depending on the seriousness and the circumstances of the offense, other forms of identification, such as a student identification card, or an employee check identification card, may be acceptable. ${ }^{101}$

\section{Whether the Offense Appears Likely to Continue}

Certain types of offenses seem more likely to continue than others. Family disputes typically fall into this category due to the continuing presence of the family members which presents a continuing irritation. These same factors also point to the threat of a more serious infraction. Offieers may exercise their discretion to effect a physical arrest in such cases in order to separate the fighting parties. ${ }^{102}$

99. Compare the experience of R.B., a 64-year-old white male, arrested for drunk driving after causing an accident, with that of L.A., a 46-year-old black male arrested on the same charge. R.B. received treatment for minor injuries and was incarcerated. Due to his intoxication he became belligerent and refused to provide any information to jail personnel. He did not receive a citation. L.A., however, sobered up in jail and became cooperative. He admitted a prior misdemeanor conviction, and stated that he had lived in Oakland for 19 years. He lived with his family, supporting them by working as a hospital orderly. He received a jail citation.

100. See note 93 supra and accompanying text.

101. For example, N.S., an 18-year-old male, received a citation after being arrested for illegal possession of alcoholic beverages by a minor. He admitted his age to the officer and produced sufficient identification. On the other hand, R.C., a 19-year-old male, arrested for petty theft, had no identification and gave false information to the arresting officer. The officer declimed to issue a citation. At the jail, a check of Department files disclosed R.C.'s real identity. It also revealed a record of 9 misdemeanors and 4 felonies, and 2 outstanding warrants. R.C. was held on the warrants. J.F., arrested with R.C., also gave false information to the officer. A check on J.F. disclosed a record of 1 misdemcanor, no outstanding warrants, and long term Oakland residence. J.F. received a citation.

102. J.D., a 39-year-old man and his wife had a serious argument. J.D. had been drinking and severely beat his wife. When the police responded to her call she told them what had happened. The arresting officer entered the D's home and found J.D. in an intoxicated and abusive state. The officer charged J.D. with a vio- 
After cooling off, the arrestee may receive a jail citation. ${ }^{103}$

\section{Whether the Arrestee Displays a Belligerent Attitude}

Although individuals charged with resisting arrest will be cited if otherwise eligible, the arrestee's attitude does not escape consideration. An individual who gives the arresting officer a great deal of difficulty will most likely be denied a field citation, ${ }^{104}$ and if the arrestee remains uncooperative once incarcerated he will usually not receive jail citation release. ${ }^{105}$

\section{Whether the Arrestee Has an Exceptionally Bad Record}

This information, usually obtained by jail personnel, can help determine whether or not to cite the arrestee. The officer makes both a quantitative and a qualitative evaluation of the arrestee's record, along with other factors. While an imdividual with a number of arrests may receive a citation release, his record certainly does not aid his cause. Generally it takes strong countervailing factors to balance a bad arrest record.

\section{Whether the Arrestee Has Outstanding Warrants Charged Against Him}

This factor, closely related to consideration of the arrestee's prior record, can carry more weight than prior convictions. ${ }^{100}$ Generally, the police will loold an arrestee to answer for any outstanding warrants. In some cases, such as ignored parking tickets, the warrants stein from minor charges. In such instances the arrestee may be cited after he

lation of Penal Code section 242 and exercised his discretion to effect a physical arrest. J.D.'s background investigation indicates that he probably would otherwise be eligible for citation release. His attitude about the offense, however, indicated to the jail officers a likelihood of recurrence. No jail citation was issued.

103. B.C. and his girl had just broken up. In a fit of rage B.C. began breaking windows and other property, as well as threatening physical injury. When the officer arrived it was apparent that the offense could continue unless B.C. was physically arrested. The officer took B.C. into custody, charging violations of Penal Code sections 415 and 594. After cooling off in the jail, B.C. received a jail citation.

104. R.P.'s case exemplifies this pattern. A caretaker caught R.P., an 18-year-old male, tresspassing along with three girls and one other boy. When stopped, all but R.P. agreed to leave. R.P. was placed under arrest by the officer summoned to the scene. When the officer informed R.P. that he was under arrest, R.P. resisted physically. The arresting officer decided against a field citation. R.P.'s background investigation revealed that he had been employed for the last 7 months as a messenger, and that he had lived at his current residence for 18 months. On the basis of this information he probably would lave received a jail release. He posted bail prior to his citation interview, however. See note 39 supra for reasons why a small number of arrestees elect bail rather than citation release.

105. Jail Interviews, supra note 39.

106. Id. 
clears the warrant. ${ }^{107}$ In the case of a defaulting defendant warrant, either outstanding or issued within the last year, an arrestee will not receive a citation. ${ }^{108}$ The issuance of a defaulting defendant warrant indicates that the arrestee cannot be trusted to appear in court.

\section{Evaluation of Citation Release in Oakland}

Between the inception of the Oakland citation program on February 23, 1970 and May 31, 1971, a total of 7,993 eligible ${ }^{\mathbf{1 0 9}}$ misdeineanor arrestees were contacted. Of that number, 2,850 (35.6 percent) received field citations; the remaining 5,143 (64.4 percent) were incarcerated. Of those incarcerated, 1,524 (29.6 percent) received jail citations. Considering both field and jail citations, a total of 4,374 persons (54.7 percent of all those contacted) received citations. ${ }^{110}$ Table $\mathrm{G}$, in Appendix $\mathrm{III}$ breaks these data into 3 month periods. ${ }^{111}$

Oakland's experience reveals a progressively decreasing default rate. ${ }^{112}$ The inost recent statistics on the rate of non-appearance show

107. Minor warrants may be cleared either by paying the outstanding fines or by making other arrangements with the court.

108. See, General Order, supra note 48.

109. L. Moody, Misdemeanor Citation Patterns (chart) in K. GUMPEL \& W. Soo Hoo, Evaluation of Misdemeanor Citations (1971) [hereinafter cited as K. GuMPEL \& W. Soo Hoo]. All statistics are on file in the Legal Division of the Oakland Police Department.

110. Id.

111. The number of elgibles contacted increased markedly in November 1970 as a result of a change in the General Order, effective on October 30,1970, that made citable several Vehicle Code offenses not previously citable. These newly included offenses may be cited only out of the jail. A second major cliange, occurring in July 1970 , allowed persons arrested on warrants to be cited. These changes coinbined to increase the percentage of misdemeanor arrestees cited and released. As of July 30, 1971 , the rate of citation release in Oakland had reached 58.6 percent of those contacted. As of July 30,1971, 37 percent of all misdemeanor arrestees received field citations. K. GUMPEL \& W. Soo Hoo, supra note 109. For purposes of perspective this rate of release should be compared to that reported by the Oakland O.R. Project of 1965:

Table 6. Disposition of Eligible Defendants Non-Traffic Misdemeanors

\begin{tabular}{lcc}
\hline & \multicolumn{2}{c}{ Non-Traffic Misdemeanors } \\
\cline { 2 - 3 } Disposition & \multicolumn{2}{c}{ Percent } \\
\cline { 2 - 3 } Jail & 33 & 1963 \\
Bail & 64 & 34 \\
O.R. & 3 & 58 \\
\cline { 2 - 3 } Totals & $100 \%$ & $100 \%$ \\
\hline
\end{tabular}

PRE-Trial ReIEASE, supra note 4, at 69.

112. As police officers worked with citation release procedures their familiarity with the system and its requirements increased. Similarly, so did their ability to assess 
that for May 1971, 4.53 percent of the 397 citation recipients failed to appear in court within 2 months, and 7.8 percent failed to appear on their first scheduled court date. ${ }^{113}$ These figures compare very favorably with the 7.5 percent default rate reported for the 1965 O.R. project. ${ }^{114}$ In comparing these figures, two facts should be noted: the O.R. project released a significantly smaller percentage of misdemeanor arrestees than does the citation release program; and, release through the O.R. project could occur only after an extensive backgound imvestigation and judicial approval. Under citation release, however, only a minimal investigation, and no judicial approval, are required.

These statistics also compare favorably to those reported for release on bail and on citation release in several jurisdictions in neighboring Contra Costa County. ${ }^{115}$ Account should be taken of three factors in making this comparison. First, the Oakland procedures are more coinprehensive than those in Costra Costa County. ${ }^{110}$ Second, Oakland issues citations to a larger percentage of its eligible arrestees. ${ }^{117}$ Third, Oakland deals with a substantially larger number of eligibles. ${ }^{118}$ As these statistics show, the police cite a majority of mis-

the likelihood of an arrestee's appearing in court. These factors, as well as increased public awareness of the program, appear to account for the decreasing rate of default.

113. OAKLand Police DeP'T., Information Bulletin Misdemeanor Citation PRogram: Jump Rate (August 20, 1971).

114. See note 49 supra. Eligible misdemeanor arrestees given positive recommendations from the Oakland project and subsequently released on their own recognizance had a default rate of 5.9 percent. Those O.R.'d in spite of the project's negative recommendations had a default rate of 16.7 percent. The combined default rate for O.R.'d misdemeanor arrestees reported for the project was 7.5 percent. Pre-Trial Release, supra note 4 , at 86 .

115. See note 50 supra. Oakland is in Alameda county which borders Contra Costa County.

116. Id. Unlike most of Contra Costa County, Oakland provides for both field and jail release.

117.

Table 7. Contra Costa County Misdemeanor Citation Releases Field or Stationhouse for One Month, 1969

\begin{tabular}{lccc}
\hline Jurisdiction & $\begin{array}{c}\text { Misdemeanors } \\
\text { Charged }\end{array}$ & $\begin{array}{c}\text { Citation } \\
\text { Releases }\end{array}$ & $\begin{array}{c}\text { Percentage of } \\
\text { Citation Releases }\end{array}$ \\
\hline Concord & 38 & 10 & 26 \\
Contra Costa & 77 & 39 & 50 \\
Sheriff & 43 & 15 & 34 \\
Pittsburg & 133 & 76 & 57 \\
Richmond & 53 & 17 & 32 \\
San Pablo & 21 & 12 & 47 \\
\hline Walnut Creek & 365 & 169 & 47 \\
\hline \multicolumn{1}{c}{ Totals } & & 169 \\
\hline
\end{tabular}

CrTation StudX, supra note 9, at 10. Compare these data with Table G, Appendix III.

118. Compare the data in Table 7, with the data for Oakland in Table G, Appendix III. 
demeanor arrestees, and the overwhelming majority of citation recipients appear in court as scheduled. As a result, judges have found little need to impose bail upon cited individuals. ${ }^{119}$

Arbitrariness and abuses of discretion are virtually undetectable on a case by case basis. If these were serious problems, however, then a trend would presumably appear in the overall statistics for the program. The demographic data reported in tables $\mathrm{A}, \mathrm{B}$, and $\mathrm{C}$ in Appendix I demonstrate that no such trend has arisen. Rather, those data indicate that differences in age, race and sex play little if any role in the officers' detcrminations whether to cite an imdividual. As these data encompass virtually every citation issued since the inception of citation release on Oakland, it appears that there has been no statistically significant amount of discriminatory or arbitrary behavior in the operation of Oakland's citation release program.

The Oakland experience with citation release lias also been financially successful. A recent cost-benefit analysis of Oakland's program disclosed large savings for the city. ${ }^{120}$

Furthermore, the willingness of the police, the District Attorney, and the judges of the Mumicipal Court to expand the prograin's scope

119. See notes 1 and 32 supra. This is allowed by CAL. Penal Code $\S 853.6(\mathrm{e})$ (West 1970).

120. L. Moody, Expenses Saved by Misdemeanor Citation Program (Apr. 23, 1971) on file with the Oakland Police Department, Office of the Legal Advisor. In preparing this study all costs were calculated at bare minimum levels. If officers' fringe benefits, for example, were included, all costs would be raised proportionally. Because no studies were made to determine actual averages, all figures given or assumed were estimated and thus set low.

Table 8. Expenses Saved by Misdemeanor Citation Program

\begin{tabular}{lc}
\hline Cost of arrest and incarceration* & \\
two arresting officers & $\$ 37.60$ \\
one arresting officer & 34.78 \\
Cost of arrest followed by jail citation** & 25.91 \\
two arresting officers & 23.06 \\
one arresting officer & 17.47 \\
Cost of arrest followed by field citation $* * *$ & 14.41 \\
$\quad$ two arresting officers & $\$ 20.37$ \\
one arresting officer & 11.72 \\
\hline
\end{tabular}

* Includes cost of arresting officer's time (average 30 minutes), squad car (transporting defendant, mileage, and officer's pay), booking, incarceration for 1 day in jail (duration often is greater), routing and completion of documents, and followup investigation. Does not include prosecution costs (pretrial conference with the District Attorney and court time for officers).

* J Jail citation eliminates cost of incarceration.

***; Field citation eliminates costs of incarceration and transportation; it reduces booking costs (booking in the jail requires an average of one hour; booking of those who appear in the Identification Section of the Pohice Department requires 15-20 minutes).

According to these data, citation release saved the city and the taxpayers of Oakland approximately $\$ 76,000$ in the 13 month period from February 23,1970 through May 31, 1971. 
provides another indication of the success of citation release in Oakland. In less than 18 months the program underwent two major expansions: In October 1970, vehicle code misdemeanors became citable and in July 1971, persons arrested on nondefaulting defendant eligible misdemeanor warrants became eligible for citation. ${ }^{121}$ But, perhaps the greatest indication of success may be found in the many requests for information and operational guidelines that the Oakland Police Department has received from other law enforcement agencies in the state. ${ }^{122}$

\section{CONCLUSION}

As evidenced by the Oakland experience, the operation of a citation release systein requires a considerable amount of planning, cooperation and organization between the police, the District Attorney, and the Municipal Court bench. Furtlermore, without formal procedures for issuance and release, officers desiring to effect such a release would be forced into arranging details for booking, court appearance, and so forth, on an ad lioc basis. These arrangeinents would be far less efficient and effective than an ordered system, and would undoubtedly vitiate many of the advantages of citation release.

Even allowing for the possibility of ad hoc releases, the burden of sucli arrangements and the absence of standardized procedures would create a strong mipetus against utilizing citation release. Section 853.6 should, therefore, be anended to ensure full utilization throughout the state. Oakland's well thought out and successful program indicates the direction of the necessary reforms.

First, the language of the aunending provisions should explicitly require each law enforcement agency to establish both jail and field citation procedures. Although some variation in standards seems acceptable in order to allow each commumity to mold the system to its needs, minimum standards inust be established below which no coinmunity may fall. Second, to ensure departmental cooperation in establishing citation release programs, a right to consideration for citation release might be recognized. While this would not mean that everyone need be released, it would establish legislative intent that all arrestees be considered and released if eligible. Failure to establish a system for consideration of arrestees for citation release could then render the department liable for the arrestee's costs in posting bail, and for reasonable attorney's fees in recovering those costs.

Finally, although Oakland's experience does not indicate that arbitrary police behavior poses a serious problem for citation release,

121. See General Order, supra note 48.

122. Final Report, supra note 59, at 4. 
should the scope of police discretion become an issue, the employment of a mandatory minimum point system for station house release would go far towards protecting against abuse. A point system patterned after that used by the Vera Institute in New York would assign numerical values to factors such as length of residence, family ties, employment, prior record, and the like. While police could be allowed discretion to release persons having fewer than the minimum number of points, all persons meeting the minimum would be automatically released.

Jeffrey $M$. Allen 


\section{APPENDIX I}

The following tables reveal the demographic characteristics of the recipients of both jail and field citations issued by the Oakland Policc Department in the month of October $1971 .{ }^{123}$

Table A. Breakdown of Citations by Recipient's Sex ${ }^{124}$

\begin{tabular}{|c|c|c|}
\hline \multirow{2}{*}{ Status } & \multicolumn{2}{|c|}{ Percentage of } \\
\hline & Males* & Females** \\
\hline Received Field Citations & 28 & 44 \\
\hline Incarcerated & 72 & 56 \\
\hline Preemptive Bails ${ }^{125}$ & 18 & 30 \\
\hline Considered for Jail Release & 82 & 70 \\
\hline Given Jail Release & 48 & 49 \\
\hline Denied Jail Release & 52 & 51 \\
\hline Received Field or Jail Release & 56 & 59 \\
\hline Denied Citation Release & 44 & 41 \\
\hline
\end{tabular}

* There were 621 potentially eligible male arrestees.

* There were 154 potentially eligible female arrestees.

123. Field citation data for this section were made available through the research facilities of the Oakland Poliee Department and is on file with the Office of the Legal Advisor. The data on jail citation recipients were compiled by the author from the records of Oakland Police Deputy Chief Sylvester who currently supervises the operations of the jail.

124. Compare these figures with those reported for the Oakland O.R. Project:

Table 9. Sex of Applicants for O.R. Non-Traffic Misdemeanors

\begin{tabular}{lcc}
\hline Sex & Number & Percentage \\
\hline Male & 537 & 82 \\
Female & 117 & 18 \\
\hline Total & 654 & 100 \\
\hline
\end{tabular}

Pre-TrIAL ReleAse, supra note 4, at 43.

125. Certain arrestees chose not to undergo the background investigation required for a citation by the jail. They either obtained bail prior to their citation interview, or refused the required information and later obtained their release through bail. See note 39 supra. 
Table B. Breakdown of Citations by Recipient's Age ${ }^{126}$

\begin{tabular}{|c|c|c|c|c|}
\hline \multirow{2}{*}{ Status } & \multicolumn{4}{|c|}{ Percentage of $\ddagger$} \\
\hline & $18-24^{*}$ & $25-34 * *$ & $35-49 * \% * *$ & $50 t^{* * * * * * 5}$ \\
\hline Received Field Citations & 22 & 25 & 27 & 44 \\
\hline Incarcerated & 78 & 75 & 73 & 56 \\
\hline Preemptive Bails 127 & 21 & 23 & 17 & 17 \\
\hline Considered for Jail Release & 79 & 77 & 83 & 83 \\
\hline Given Jail Release & 35 & 51 & 52 & 63 \\
\hline Denied Jail Release & 65 & 49 & 48 & 37 \\
\hline Received Field or Jail Release & 43 & 56 & 59 & 61 \\
\hline Denied Citation Release & 57 & 44 & 41 & 39 \\
\hline
\end{tabular}

\$ The records bore no indication of the ages of 10 recipients of field citations.

* There were 223 arrestees in this category.

* There were 223 arrestees in this category.

$\Rightarrow+$ There were 203 arrestees in this category.

There were 166 arrestees in this category.

126. Compare these figures with those reported for the 1965 Oakland O.R. Project:

Table 10. Age of Applicants for O.R. Release Non-Traffic Misdemeanors

\begin{tabular}{lcc}
\hline Age & Number & Percentage \\
\hline $18-25$ & 284 & 43 \\
$26-30$ & 98 & 15 \\
31 and over & 272 & 42 \\
\hline Totals & 654 & 100 \\
\hline
\end{tabular}

Pre-Trial Release, supra note 4, at 43.

127. See note 125 supra. 
Table C. Breakdown of Citations by Recipient's Race ${ }^{128}$

\begin{tabular}{|c|c|c|c|c|}
\hline \multirow{2}{*}{ Status } & \multicolumn{4}{|c|}{ Percentage of } \\
\hline & Black* $^{*}$ & White** & Chicanotint & Other \\
\hline Received Field Citations & + & + & 宷 & \$ \\
\hline Incarcerated & 1004 & 100: & 100: & 100: \\
\hline Preemptive Bails ${ }^{129}$ & 23 & 17 & 18 & 10 \\
\hline Considered for Jail Release & 77 & 83 & 82 & 90 \\
\hline Given Jail Release & 45 & 53 & 48 & 47 \\
\hline Denied Jail Release & 55 & 47 & 52 & 53 \\
\hline \multicolumn{5}{|c|}{$\begin{array}{l}\text { \$ Statistical information on the racial characteristics of persons receiving field release } \\
\text { was not available; therefore, this table treats the number incarcerated as } 100 \text { percent. } \\
\text { There were } 304 \text { arrestees in this category. } \\
* \text { There were } 202 \text { arrestees in this category. } \\
* * * \text { There were } 43 \text { arrestees in this category. } \\
* * * \text { There were } 21 \text { arrestees in this category. }\end{array}$} \\
\hline
\end{tabular}

128. Compare these figures with those reported for the 1965 O.R. Projeet:

Table 11. Ethnic Background of Applicants for O.R. Non-Traffic Misdemeanors

\begin{tabular}{lcc}
\hline Ethnic Background & Number & Percentage \\
\hline White & 203 & 31 \\
Black & 386 & 59 \\
Chicano & 37 & 6 \\
Asian & 0 & 0 \\
Other & 28 & 4 \\
\hline
\end{tabular}

PRE-TrIAL ReleAse, supra note 4 , at 44.

129. See note 125 supra. 


\section{APPENDIX II}

The following tables break down by offense all jail citations issued by the Oakland Police Department for the month of November 1970. ${ }^{130}$

Table D. Breakdown by Offense of Citations to Incarcerated Arrestees November 1970

\begin{tabular}{c|c|c}
\hline $\begin{array}{c}\text { Penal Code Offense* } \\
\text { (by section number) }\end{array}$ & $\begin{array}{c}\text { Number } \\
\text { Incarcerated }\end{array}$ & $\begin{array}{c}\text { Percentage Cited } \\
\text { in Jail }\end{array}$ \\
\hline 148 & 8 & 37.5 \\
240 & 1 & 0 \\
242 & 28 & 17.9 \\
314 & 1 & 0 \\
330 & 2 & 100.0 \\
$367 \mathrm{~d}$ & 1 & 0 \\
372 & 1 & 0 \\
$374 \mathrm{~b}$ & 1 & 100.0 \\
415 & 23 & 4.4 \\
417 & 2 & 0 \\
466 & 3 & 33.3 \\
484 & 86 & 22.0 \\
$484 \mathrm{f}$ & 2 & 0 \\
$602 \mathrm{~L}$ & 1 & 0 \\
$602 \mathrm{~N}$ & 1 & 0 \\
626.8 & 4 & 0 \\
$647(\mathrm{c})$ & 1 & 0 \\
$647(\mathrm{e})$ & 1 & 0 \\
$647(\mathrm{~g})$ & 1 & 0 \\
$653 \mathrm{~g}$ & 1 & 0 \\
$653 \mathrm{k}$ & 2 & 50.0 \\
12025 & 11 & 27.2 \\
12031 & 2 & 50.0 \\
& 1 &
\end{tabular}

* There were 184 persons charged with Penal Code violations.

130. K. GuMPEL \& W. Soo Hoo, supra note 109, at 10-14. 
Table E. Breakdown by Offense of Citations to Incarcerated Arrestees November 1970

\begin{tabular}{l|c|c}
\hline $\begin{array}{l}\text { Vehicle Code Offense* } \\
\text { (by section number) }\end{array}$ & $\begin{array}{c}\text { Number } \\
\text { Incarcerated }\end{array}$ & $\begin{array}{c}\text { Percentage Cited } \\
\text { m Jail }\end{array}$ \\
\hline 10852 & 2 & 0 \\
12951 & 35 & 11.4 \\
12951 (CHP ACCOM.) & 1 & 0 \\
$20002 \mathrm{a}$ & 2 & 0 \\
21451 & 1 & 0 \\
$21453 \mathrm{a}$ & 2 & 0 \\
$21453 \mathrm{~b}$ & 1 & 0 \\
21456 & 1 & 0 \\
$21457 \mathrm{a}$ & 1 & 0 \\
21461 & 3 & 33.3 \\
21658 & 1 & 0 \\
21712 & 1 & 0 \\
$21954 \mathrm{a}$ & 1 & 0 \\
21955 & 3 & 0 \\
21957 & 2 & 0 \\
$22100 \mathrm{~b}$ & 1 & 0 \\
22107 & 3 & 33.3 \\
22349 & 1 & 0 \\
22350 & 18 & 16.6 \\
22450 & 2 & 0 \\
$23102 \mathrm{a}$ & 83 & 27.7 \\
$23102 \mathrm{a}$ (CHP ACCOM.) & 106 & 31.1 \\
23103 (CHP ACCOM.) & 1 & 0 \\
23122 & 1 & 0 \\
$40302 \mathrm{a}$ & 1 & 0 \\
$40504 \mathrm{~b}$ & 1 & 0 \\
"TRF. CHG'S" & 20 & 20.0 \\
\hline
\end{tabular}

* There were 295 persons charged with Vehicle Code offenses. 
Table F. Breakdown by Offense of Citations to Incarcerated Arrestees November 1970

\begin{tabular}{l|c|c}
\hline $\begin{array}{c}\text { Miscellaneous Offenses* } \\
\text { (by code and section number) }\end{array}$ & $\begin{array}{l}\text { Number } \\
\text { Incarcerated }\end{array}$ & $\begin{array}{c}\text { Percentage Cited } \\
\text { in Jail }\end{array}$ \\
\hline Health \& Safety Code & & \\
11170 & 1 & 0 \\
11555 & 5 & 0 \\
11556 & 1 & 0 \\
11915 & 3 & \\
Oakland Municipal Code & 5 & 0 \\
2-7.02 & 1 & 0 \\
$3-4.01$ & 20 & \\
3-5.06 & & 100 \\
Oakland Traffic Code & 1 & \\
235 & &
\end{tabular}

* There were 43 persons charged with offenses listed in this table.

Alcoholic Beverage Control Code

1

Alcoholic Beverage Control Code

25662

Warrants

270 (Penal Code)

626.8 (Penal Code)

3-9.12 (Oakland Municipal)

Traffic Surrender

14601.1 (Health \& Safety)
1

10

$\begin{array}{lr}1 & 100 \\ 1 & 0 \\ 1 & 100 \\ 1 & 0 \\ 1 & 0\end{array}$

* There were 44 persons charged with offenses listed in this table. 


\section{APPENDIX III}

Appendix III presents a brief statistical summary of the operations of citation released in Oakland. In reading Table $\mathrm{G}$, a declining rate of citation issuance will be noted for the period of March 1970 through February 1971. There is no official explanation for this phenomenon. Most likely, the officers were at first unsure of the procedures involved and therefore cited persons who were not eligible or who were bad risks. As officers became more familiar with the procedures, and more confident of their ability to detect bad risks, the practice of citation issuance changed accordingly. The imcrease rate of issuance beginning in March 1971 can be attributed to this greater expertise, as well as the increased scope of the program.

Table G. Patterns of Citation Issuance in Oakland ${ }^{131}$

\begin{tabular}{|c|c|c|c|c|c|}
\hline \multirow[b]{2}{*}{ Status } & \multicolumn{5}{|c|}{ Period of } \\
\hline & $\begin{array}{c}\text { Mar-May } \\
1970\end{array}$ & $\begin{array}{l}\text { Jun-Aug } \\
1970\end{array}$ & $\begin{array}{l}\text { Sep-Nov } \\
1970\end{array}$ & $\begin{array}{l}\text { Dec-Feb } \\
1970-71\end{array}$ & $\begin{array}{c}\text { Mar-May } \\
1971\end{array}$ \\
\hline $\begin{array}{l}\text { Total Number of Ehigibles } \\
\text { Percentage of Ehigibles }\end{array}$ & 1325 & 1163 & 1122 & 1988 & 2114 \\
\hline $\begin{array}{l}\text { Cited in Field } \\
\text { Percentage of Incarcerated } \\
\text { Arrestees Given Jail }\end{array}$ & 48 & 47 & 41 & 26 & 33 \\
\hline $\begin{array}{l}\text { Citations } \\
\text { Percentage of Total Numbe } \\
\text { of Eligibles Cited in }\end{array}$ & er & 30 & 20 & 29 & 31 \\
\hline Field and Jail & 67 & 63 & 58 & 48 & 54 \\
\hline
\end{tabular}

131. Id. See note 111 supra. 